\title{
Spanish, Portuguese, and Neo-Latin Poetry Written and/or Published by Seventeenth-, Eighteenth-, and Nineteenth-Century Sephardim from Hamburg and Frankfurt (2)
}

\author{
Kenneth BROWN \\ University of Calgary \\ Reyes BERTOLÍN CEBRIÁN \\ University of Calgary
}

Part Two of this extended study ${ }^{2}$ includes seventeen additional

\begin{abstract}
${ }^{1} \mathrm{~K}$. Brown herein wishes to express his sincere appreciation to the following individuals and institutions for helping to promote the present study: the Deutscher Akademischer Austauschdienst (New York City), for providing him a three-month «Travel/Research Grant» to Wolfenbüttel, Frankfurt, and Hamburg, for fall 1998; Dr. Michael Studemund-Halévy, personal friend and Hamburg savant, who unselfishly provided him the seven lapidary inscriptions, much-needed bibliography, constant encouragement, and the fruits of his own scholarly research on the Hamburg-based Sephardim; Dr. Jill Bepler, Vice-Director, and Christian Hogrefe, Chief Librarian, The Herzog August Bibliothek (Wolfenbüttel), whose heightened sense of professionalism made his sojourn at the research library enormously worthwhile. The authors acknowledge herein permission from the Herzog August Bibliothek directors to reproduce rare texts from their collection in this study; and K. Brown thanks Susan Rosenstein and Dr. John O'Neil, the Hispanic Society of America, for providing him ready access to scores of rare printed books in the HSA collection during his visit to the institution in May 1999. Information concerning these texts is included with the express permission of The Trustees of the Society.

${ }^{2}$ The first appeared in Sefarad 59 (1999) pp. 3-42. The following is a list of errata and additions to Part One. (Pp. 3-4) Population figures are inaccurate; STUDEMUND-HALÉVY 1999a:2, provides more precise statistics: «Sefardische Juden in Hamburg und Altona»: 1600,$150 ; 1640,600 ; 1652,1.250 ; 1700,450 ; 1800$, $375 ; 1900,275 ; 1933,250 ; 1938,85$. (P. 4) Mosé Abudiente was born ca. 1610. (P. 4)
\end{abstract}


complete poems in Portuguese, Spanish, and Neo-Latin ${ }^{3}$. Two of the seventeen are of questionable authorship by Sephardim (nos. 37-38): they appear to be the works of Portuguese NewChristian physicians, but whether these individuals were professing Jews is unknown. The Introduction includes a rationale for defending the hypothesis -already summarily advanced in Part One (Brown 1999b: p. 15, n. 38)- that several theological, medical, classical and practical works written by Sephardim were printed at Frankfurt am Main during the period 1614-1632, and that this editorial process continued occasionally until the end of the seventeenth century. Therefore, frontispieces bearing a Frankfurt-amMain place of publication were not false or deceptive, «fronting» as it were for manuscripts actually published by Hamburg- or Amsterdam-based printers. Such has been argued until now (Studemund-Halévy 1997d, 1999a, 1999b, 1999c:18; Boer 1989:6768 and 1992:52) ${ }^{4}$. Our contention is that Gedruckt in Frankfurt am

Abraham Meldola died on 25/11/1826. (P. 4) Binjamin Mussaphia died on 11/12/1674 in Amsterdam (12 Kislev 5435); he was the author of Sententiae SacroMedicae (Hamburg 1640, and Frankfurt am Main 1649) (STUDEMUND-HALÉVY 1997e:42, n. 97). (P. 4) Altona was Danish only from 1640 onward. (P. 33 n. 69) The poem was originally contained in David Coen de Lara's 1633 Spanish translation of Elyá ben Mošé Vidas' Tratado del temor divino ... traducido nuevamente del Hebrayco, a nuestro vulgar idioma (BOER 1992:386, entry 16). (P. 32) Poem 14 v. 2, which begins Quid mentita ..., should read «Vitam tunc». (P. 6 n. 13) Arturo FARINELli's essay (1892) may be added.

Abbreviations employed in this study are: Arquivo da Universidade de Coimbra $=$ AUC; Encyclopaedia Judaica $=E J ;$ Herzog August Bibliothek, Wolfenbüttel (Germany) = HAB; Hispanic Society of America = HSA; The National Union Catalog Pre-1956 Imprints = NUC; Universitätsbibliothek Hamburg = UBH; Yale University Sterling Memorial Library = YUSML.

${ }^{3}$ For the time being, the authors have excluded works in Hebrew.

${ }^{4}$ Even in the Catalogue of Books Printed Vol. I, C6, corresponding to Francisco de Cáceres' 1616 Spanish translation of Niccolò Franco's Dialogui Satiriche, the Frankfurt place of publication is considered doubtful, with Amsterdam suggested as an alternate possibility. I beg to differ with all those who discount Frankfurt am Main as the publishing center for Sephardic-authored books. This includes my esteemed colleagues Harm den Boer and Michael Studemund-Halévy. STUDEMUND-HALÉVY 1997d:90 accepts Hamburg as place of publication of Abenatar Melo's works: «David Abenatar Melo kommt als reifer Mann nach Amsterdam und bringt dort auf eigene Kosten drei Bücher zum Druck. Wenig später zieht er nach Hamburg, wo er sein Hauptwerk, die Übersetzung der Psalmen, veröffentlicht». He repeats this assertion in 1997f:10 and 158, as well as in 1997e:45, under the section heading Druckort ('Place of publication'): «Amsterdamer Autoren wie Francisco de Cáceres ... lassen ihre Bücher mit den fingierten Druckorten 
Main meant 'Printed in Frankfurt [פרנקפורט] on the Main [and nowhere else]', and that when the Sephardic Francisco de Cáceres completes his short dedication to his Frankfurt printed and published 1616 Spanish translation of Niccolò Franco's Diálogos satíricos, signing off «De Francaforte à primero de Diziembre, de 1616", he must have been physically present in that Germanspeaking city. An Appendix includes four letters of personal correspondence written by or directed to members of the seventeenth-century Hamburg Sephardic community, all of whom men of science -Dr. Jacob Rosales (1588-1662) ${ }^{5}$, Dr. Abraham Zacuto (1575-1642) ${ }^{6}$, Dr. Rodrigo de Castro (David Nehamías) (15461627) ${ }^{7}$ and his son Dr. Benito de Castro (Baruch Nehamías)

Antwerpen, Frankfurt [am Main] und Brüssel erscheinen. Hamburger Autoren wie Ishac de Castro, Semuel da Silva, David Abenatar Melo und Mosseh Gideon Abudiente geben fingierte Druckorte wie Amsterdam, Frankfurt [am Main] oder Glückstadt an».

This information would appear to somewhat compromise what is stated in 1997g:151: «Da der bedeutendere holländische Buchmarkt für die Hamburger Portugiesen natürlich viel interessanter war, bezogen sie ihre Bücher in hebräischer, portugiesisicher und spanischer Sprache vor allem aus Amsterdam. Und weil in Hamburg zu keinem Zeitpunkt eine jüdische-sephardische Presse bestand und eine hebräische Typographie nicht vor 1680 nachzuweisen ist». BOER 1989:67-68, states that Francisco de Cáceres' 1616 edition of Niccolò Franco's Diálogos satíricos boasts a false «Francaforte» frontispiece («fictieve drukplaats») in order to appeal to a wider Spanish-Christian reading public: «Er is niets in de Diálogos satýricos waardoor het werk zich in het bijzonder richtte tot de Sefardische joden. De titeluitgave van de Diálogos satýricos met het gefingeerde drukkersadres "Francaforte", en de opdrachten van beide uitgaven aan niet-joodse beschermheren geven juist aan, dat de auteur een verspreiding zocht onder een zo groot mogelijk Spaanslezend publiek». See also BOER 1988a and 1992:51-55.

${ }^{5}$ For bibliography concerning Rosales, see STUDEMUND-HALÉVy 1994:57-58 (nos. 860-871), and, especially, WINIGER 223-224, KELLENBENZ 1956 (no. 864), and SARAIVA 1986 (no. 871).

${ }^{6}$ For Abraham Zacuto, see LEMOS 1909.

${ }^{7}$ For Rodrigo de Castro, who died on 15 Shevat 5387 (20 Jan. 1627), see STUDEMUND-HALÉVY 1994:52 (nos. 797-805), and, especially, SCHLEINER 1994, and FRIEDENWALD 1944 and 1946. He was the author of the following major medical treatises: Tractatus brevis de natura et causis pestis quae hoc anno 1596 (Hamburg: Jakob Lucius); De universa mulierum morborum medicina (Hamburg: G. L. Frobeniano, 1603; subsequent eds.: Hamburg 1604, 1617, and 1628, Venice 1644, Hamburg 1662, Cologne 1689); and Medicus-Politicus (Cologne and Hamburg 1614). The 1664 [and later 1668] Hannover - Frankfurt-am-Main Tractatus de natura muliebri, seu disputationes ac lectiones Pisanae. Nunc primum in lucem editus (printed in Hannover; paid for by Christophori Le-Blon, of Frankfurt; and typeset by Ioannis Aubri, of Frankfurt), had been a previously unedited gynecological work, prepared for press eventually by Francisco de Castro, 
(1597-1684) ${ }^{8}$. Their provenance is the HAB manuscript collections.

Rodrigo's eldest son. The editorial history of this last work connects Rodrigues de Castro to both Frankfurt and Pisa.

Citing STUDEMUND-HALÉVY 1997d:86, who quotes from Miguel de Barrios', «Relación de los poetas y escritores de la nación amstelodama»: «Rodrigo de Castro, Médico del Senado de Hamburgo, hizo dos famosos libros, uno de la enfermedad de las Mugeres, y otro del Médico Político, y su hijo Benedito de Castro fue Médico de la Reyna Christina de Suecia». The question still remains whether Rodrigo de Castro (1546-1627) was the same individual as Estêvão Rodrigues de Castro/Stephanus Rodericus Castrensis Lusitanus (1560-1638) (Cfr. MANUPELla Ed.), professor of medicine at Pisa in the era post-1613-. Despite Manupella's attestations in his impressive piece of scholarship on the physician's Italian period and multilingual creative literature (Ed. 1967:ix), such as «... vejome obrigado a lembrar que o Dr. Estêvão Rodrigues de Castro -médico, cientista e consumado humanista de formação coimbrã, poeta bilíngue ...- não era espanhol, nem era "judaizante"», it would appear that he was, indeed, mistaken about E. R. de Castro's religious convictions and his dual personae. When Rodrigues de Castro referred, poetically, to his «iura laris» (MANUPELlA Ed. 1967:63), he meant the 'law of his forebears': that is, Judaism. Estêvão Rodrigues de Castro's eldest son, Francisco de Castro, who had edited at least one of his father's posthumous medical manuscripts, the Tractatus de natura mulieri (Frankfurt am Main 1668), and who also may have edited his father's Posthuma (Florence: Massa, 1640-1646), authored the profane Metamorphoses a lo moderno ... (Florence 1641), the HSA copy of which bears the following inscription: «K.K. $258 \mathrm{v} »$, referring no doubt to a synagogue shelflist: $K$. $K$. being an abbreviation for Kahal Kadoš. This is purely circumstantial evidence, at best. However, one should add to this Estêvão Rodrigues de Castro's circle of professional cohorts, all of whom former students at Coimbra, including Abraham Zacuto (MANUPELLA Ed. 1967:112), António Dias Pinto and Bento Pinhel (MANupella Ed. 1967:31-33), to a man documented as professing Jews. Manupella admits to António Dias Pinto's judaism, but merely dismisses Bento Pinhel as a «lisboeta errante». Zacuto is not discussed. Both Dias Pinto and Pinhel were part of a crypto-Jewish community in Florence in the early 1620s (BROWN 1999a:51, and LARAS 1978:95). Estêvão Rodrigues de Castro's medical works while in Florence and Pisa deal with gynecology and the plague, subjects central to the Hamburg-based Rodrigues de Castro's publications. What remains perplexing, though, is Manupella's dating of Estêvão Rodrigues de Castro's life: 1560-1638.

${ }^{8}$ For Baruch Nehamías de Castro, see $\mathrm{n} .7$ above, in addition to STUDEMUNDHALÉVY 1994:52 and 1997d:42 n. 96: «Zu Baruch de Castro siehe Friedenwald 1944:II, 448-459, Schleiner 1994:159». Studemund-Halévy provides the following bibliography of medical texts authored by this individual: Tratado da calumnia, em o qual brevemente se mostrão a natureza, causas e effeitos desde pernicioso vício; e juntamente se apuntão dous remédios delle (Antwerpen 1629; Latin translation Amsterdam 1631); under the pseudonym Philotheo Castelo, Monomachia, sive Certamen Medicum (Hamburg 1647). 
The present anthology significantly broadens the registers of poetry contained in Part One, in which circumstantial verse, sporadically written for poetic contests in Spanish or Portuguese in commemoration of inquisitorial martyrs, is the norm, not the exception. What characterizes the present new corpus poetarum are intricate, sometimes pedantic, neo-classical, Neo-Latin distiches explicating Platonic or Neo-Platonic philosophy -for instance, Jacob Rosales' «Exponam dubium» (poem 29) and his Epos Noêtikon (poem 32)-, examples of Baroque metametrics (poem 31, a goblet and, possibly, 46a, a funereal urn), and copious references to pagan mythology and classical literature. All evidence a strict adherence to classical conventions and their metrics. As well, there are simple, Portuguese-language funerary dirges penned by a local Hamburg scribe or poet for hire and sculpted with great care into tombstones that have withered the storms of centuries. Herein also is facile, «neo»-gothic courtly love poetry included in a bi-lingual Portuguese-German dictionary prepared for purposes of international commerce and wrought on the influence of a stray couplet. In our anthology, Minerva and Adonay, Clio and Moses, an Iberian scholastic university education and formative yeshivah studies, European mercantilism, learning languages for fun and profit voices from the tomb, and unrequited love combine to provide a fascinating window to the literary creativity of the seventeenth-, eighteenth- and early nineteenth-century Hamburg Sephardim. The novelty of Part Two is not only quantitative - that is, expanding the corpus poetarum from twenty-eight to forty-five works-, thematic and stylistic, but also chronological, for it extends the creative muse beyond 1785 (terminus ad quem established in Part One) to the third decade of the nineteenth century.

In addition to Spanish, Portuguese, and Neo-Latin (and the temporarily excluded, but not forgotten, Hebrew verse; a subject for future analysis), Classical Greek finds its way into Jacob Rosales' elegaics. This Portuguese-Jewish scientist, philosopher and poet -an authentic humanist- recalls the intellectual/linguistic ambiance of the Iberian university (Cfr. Pérez Ibáñez 1997:21, sect. II, on «Humanismo Médico») as he employs Ovid's Elegiac couplet and Horace's Sapphic Strophe in his Odes in a deft attempt to ponder the mysteries of humankind: he combines verses from the Song of Songs, refers insistently to Judaic oral law and 
the rite of circumcision, explores the importance of death and good deeds, and adds the practical need to improve a mother's chances for survival in childbirth. But even in his scientific disquisitions, Galen's medicine is subservient to the God of the Hebrews. In the Carmen Intellectuale, for instance, Adonay is 'Rector of the heavens' (32.I.9: «Ex rectore poli producta scientia»). Jewish orthodoxy prevails. The colloquial Zacuto's Latin is purely utilitarian and less-than-elegant as he lashes out at detractors.

Medicus Hamburgensis and Lusitano in Part Two become coterminous with Sephardic Jew. In fact, Jacob Rosales proudly proclaims himself «Medici Hebraei» (poem 31 below), the Frankfurtam-Main Protestant doctor of medicine and university professor Johannus Jonstonus hails Zacuto in the vocative «O Hebraicae!» ,

9 «Zacuto Lusitano medico incomparabili, Ioannes Ionstonus, Medicus, \& inclytae Academiae Francofurtensis Professor Ordinarius. - Historiae tuae, Zacute eminentissime, ita summorum medicorum, totius orbis animos inflammarunt, ut nihil aliud cogitent, quam eas legere, revidere, memoriae mandare, \& recte, meo voto, id faciunt: nam, qui Zacuti opera legit, Galenum legit: ea enim solum ex facundissim[i] hujus auctoris, \& aliorum Principum medicorum sententiis illustribus, oraculisque, sunt exhausta, ita procerum tutela, \& doctrina ita strenue dimicas, \& facies tuas Herculeas contra novatorum tela disponis, ut brevi temporis momento, ea irrita reddas, exanguia, \& pene nulla. O Hebraicae! imo Lusitanae familiae sidus splendissimum. O! Medici chori fulgentissimum jubar. O! literatorum unicum assylum. Vigent bella, Bellona fremit, Mars saevit, major pars orbis ad arma concurrit, Medici velut exanimes jacent, imo languidi torpent, \& inertes. Medicina flocci fit, praecipiti lapsu ruit. Tu eam hoc modo infaeliciter humi prostratam erigis, illius alumnos ad studentum accendis, \& eruditissimis scriptis tuis beas, \& refocillas. Maximas tibi gratias praesto, quod in tuis operibus, de meis admirandis ita recte sentias, cum ita sit, incultum hactenus me habui modo tuo suffragio evectus, aliquid me scire existimabo. Vale Zacute, ter acutissime, \& Ionstonum tuum literis tuis consalutare singulis nundinis velis obnixe precor. Ex inclyta Francofurtensi civitate 14. die Augusti Anno 1641» (Zacutus Historiarum: Liber Ultimus 1642 fol. 7) ('Zacuto Lusitano, incomparable physician. [From] Joannes Jonstonus, physician and «ordinary» professor of the celebrated Frankfurt Academy. The Great Zacuto: Your histories have kindled the minds of the world's greatest doctors in such a way that they spend all their time reading them, revising them, and memorizing them. And, in my wisdom, they do well. He who cites Zacuto's works, cites Galen. Since only these [works] are out of print among all their author's extremely eloquent titles, and they also [stand out] among the illustrious sayings and oracles of other princes of medicine. You proceed so efficiently with the knowledge of the great physicians and their doctrine, and you wield your Herculean being against the weapons of the young ones, such that in a short time you leave them annoyed, exhausted and almost worthless. Oh shining star, not only of the Jewish family, but also of Portugal! Oh brilliant splendor of the medical choir! Oh bastion of letters! Wars are raging, Bellona roars, Mars is crazed, and the greater part of the world is marching at arms. The doctors of 
and Cornelius Ullefeld of Sweden addresses Baruch de Castro as «Medicum Judaeum» (Appendix 4). Conversos involved in medical science were not an entirely new phenomenon in the history of medicine in the Iberian Peninsula (Cfr. Pérez Ibáñez 1997:47, 60-64, 66$71,73,76$ ), but in our case the physicians were professing Jews.

The sociological bits of personal information these poems and the appended texts provide tell a compelling story of the Hamburg-based physical-science-minded Sephardim: Rosales (Appendix 1 ls. 7-8) came (or fled) to German-speaking lands in search of 'more [religious qua intellectual] freedom'. In the letter from $\mathrm{Za}-$ cuto to Rodrigo de Castro (Appendix 2 ls. 13-14), the author cites a rabbinical source -Rabbi Moses in his aphorisms- to support an argument ascertaining the superior physician from the mediocre one. We read of mutual friendships between Sephardim and Protestant men of science and government, of admiration by Sephardim of the ruling Protestant powers that be: Beverovicius (Zacutus Historiarum: Liber Quintus 1639 fol. 5r), Ullefeld (Appendix 4), Joannes Antonides Van der Linden (Zacutus Historiarum: Liber Septimus 1641 fol. 25), Jonstonus (Zacutus Historiarum: Liber Ultimus [ $=11] 1642$ fol. 7), and the Herzog August Junior ${ }^{10}$. Medicine, science and poetry mix -a phenomenon which would much later characterize Iberian culture in the figures of Pío Baroja, Santiago Ramón y Cajal and Pedro Laín Entralgo, though not an uncommon occurrence in the renaissance: Galileo is an apt example ${ }^{11}$.

Noteworthy are the seven funerary inscriptions in verse -called in German Begräbnisgedichte- eulogizing five deceased women

medicine are lifeless, languid and inert, as well as befuddled. Medicine is accorded no importance: it is downtrodden. You have given medicine new life, which previously had been so indignantly prostrate in the dust. You have envigorated your students toward study and have delighted and excited them by your extremely erudite written works. I thank you profoundly for the wisdom in your books. Hear my admiration for you, such that I consider myself uncultured when I compare myself to your erudition: it is bewildering to me, [so much so that] I can now safely say that I know something. Many times Godspeed, Zacuto! You are so intellectually sharp: I obstinately beseech you that you visit your Jonstonus with a letter within nine days. From the glorious city of Frankfurt. 7 August 1641').

${ }^{10}$ See Castro Lusitani 1617. The dedication on p. a2, to the Herzog August Junior of Braunschweig, [Wolfenbüttel] and Lüneburg, reads as follows: «Illustrissimo atque Generosissimo Principi ac Domino, Don Augusto Juniori, Brunswicensium ac Lunaeburgensium Duci, Domino meo Clementissimo».

$"$ See Dava Sobel, Galileo's Daughter (Toronto: Viking, 1999) pp. 10-11, 326. 
and two men, with Portuguese the language of linguistic choice (see Faust and Studemund-Halévy 1996, 1997a and 1997b). Brief as they may be, these verses allow us specific biographical insights into the Sephardic Community and the marital life of its women (nos. 39-41, 44-45). The inscription to Miriam Coronel's remains consecrates the ground as "O poço de Miriam», a romantic gathering place for family and friends to venerate her spirit; Angela Miriam Abendana Mendes provided alms to orphans and widows, probably by generously supporting a beneficent society, similar if not identical to Amsterdam's $O$ Dotar ${ }^{12}$. Married 42 years, she served her husband faithfully. Rahel Rodrigues Mendes succumbed at too early an age as did Rahel Hana Abudiente, who represented one of the more influential Sephardic families in Hamburg. Perhaps they were victims of the bubonic plague, which was devasting Europe during the times of the Thirty Years War. Though most likely the commissioned works of for-profit commercial versifiers (the earliest of whom had a penchant for culteranista word choice), we can still glean from these funerary pieces distant feminine voices recalling from the tomb salient events of these forgotten women's lives: they tell a constant tale of virtue and self sacrifice, filtered as it were by masculine voices (Brown 1999a). Nothing comparable emerges from the tombstone inscriptions of the two deceased men: Eliau Semuel Israel Baruch (42) and Jacob Álvares de Vargas (43).

Those who question the bookprinting of Sephardic-authored titles in Frankfurt am Main do so without providing or substantiating the burden of proof to the contrary. Den Boer's strong argument concerning falsification of frontispieces for seventeenth-century Sephardic-authored texts printed in Amsterdam though bearing Antwerp place of publication (for said reason, aimed at breaking the commercial book embargo against anything having to do with the heterodox Dutch Netherlands, and, consequently, destined to a wider Spanish, that is Catholic, reading public and export market) does not appear to hold the same sway for Frankfurt-based imprints (Boer 1992:51-55, especially 52; 1989).

To wit, Amsterdam's Calvinist-controlled municipal government and its booming bookmarket did indeed vie with Catholic Ant-

12 'Founded by Rabbi Joseph Pardo of Amsterdam and Jacob Coronel of Hamburg' (STudemund-Halévy 1999c:7 n. 14). See Bodian 1987:30-61; also W. Chr. PieTERSE (Coord.), 350 Jaar Dotar (Amsterdam 1965), and L. HAGOORT, Index op Santa Companhia de Dotar Orfas e Donzelas, Amsterdam (n.d.). 
werp's. Frankfurt, though, was also a Lutheran stronghold, and the major city presses at the onset of the seventeenth century, many controlled by the Calvinist Wechsel-Aubri dynastic network, encouraged the publication of old and new scientific treatises, and were open to religious heterodoxy while also encouraging highbrow humanism (Evans 1975:12-13, 14, 20, 25, 31-32, 34, 37-38, 43$45,48,51-52)$.

Despite Vincenz Fettmilch's horrorific 1614 pogrom which decimated much of the Ashkenazi ghetto ${ }^{13}$, normality quickly resumed, the culprits were hanged, and the German-speaking Ashkenazi Jewish population was immediately conceded greater protection (EJ 7:84-86). That says nothing for a small population of Sephardim in the city's environs, a group allied to the Ashkenazi minority in religious beliefs alone, though remote from them in their Iberian upbringing and ethnic background.

The authors of this study see a recognizable pattern emerging from the quantifiable titles authored by both Sephardim and their converso half-brethren on their way to reconversion: Frankfurt was, as it still is, the European printing centre and book distribution fair/market par excellence, where one could have any book in any one of several European major languages translated and printed for a highly attractive, competitive price. Frankfurt may also have been a stopping-off place for soon-to-be-reconverted marranos en route to cities of safer haven: Hamburg, Amsterdam, Leghorn, and Venice.

It is no wonder that many genuinely Sephardic-authored books bear the explicate Sumptibus Auctoris ('Publication] Paid for by the author') or nothing at all concerning the typesetter and printer on their frontispieces. Our contention is that authors such as Menasseh ben Israel and David Abenatar Melo had their works printed in Frankfurt because it was the most economical means of production. Other Sephardim obviously came to Frankfurt, manuscript in hand and cash in pocket, only to then return to Amsterdam and Hamburg with boxes of their newly-printed books to sell among their coreligionaries back home. It must have been smart business.

${ }^{13}$ See FuKS - FUKS-MANSFELD 1984:189, no. 255: «Megilas Vinz, poem on the calamities of the Jews in Frankfurt-on-the-Main during the riots caused by Vincenz (Vinz) Fettmilch (1614), by Elhanan ben Abraham Hellin, Hebrew with Yiddish translation. Financed by Nathan $b$. Abraham Hellin, grandson of the author» (2nd ed. Amsterdam 1648; copy in the Bibliotheca Rosenthaliana). 


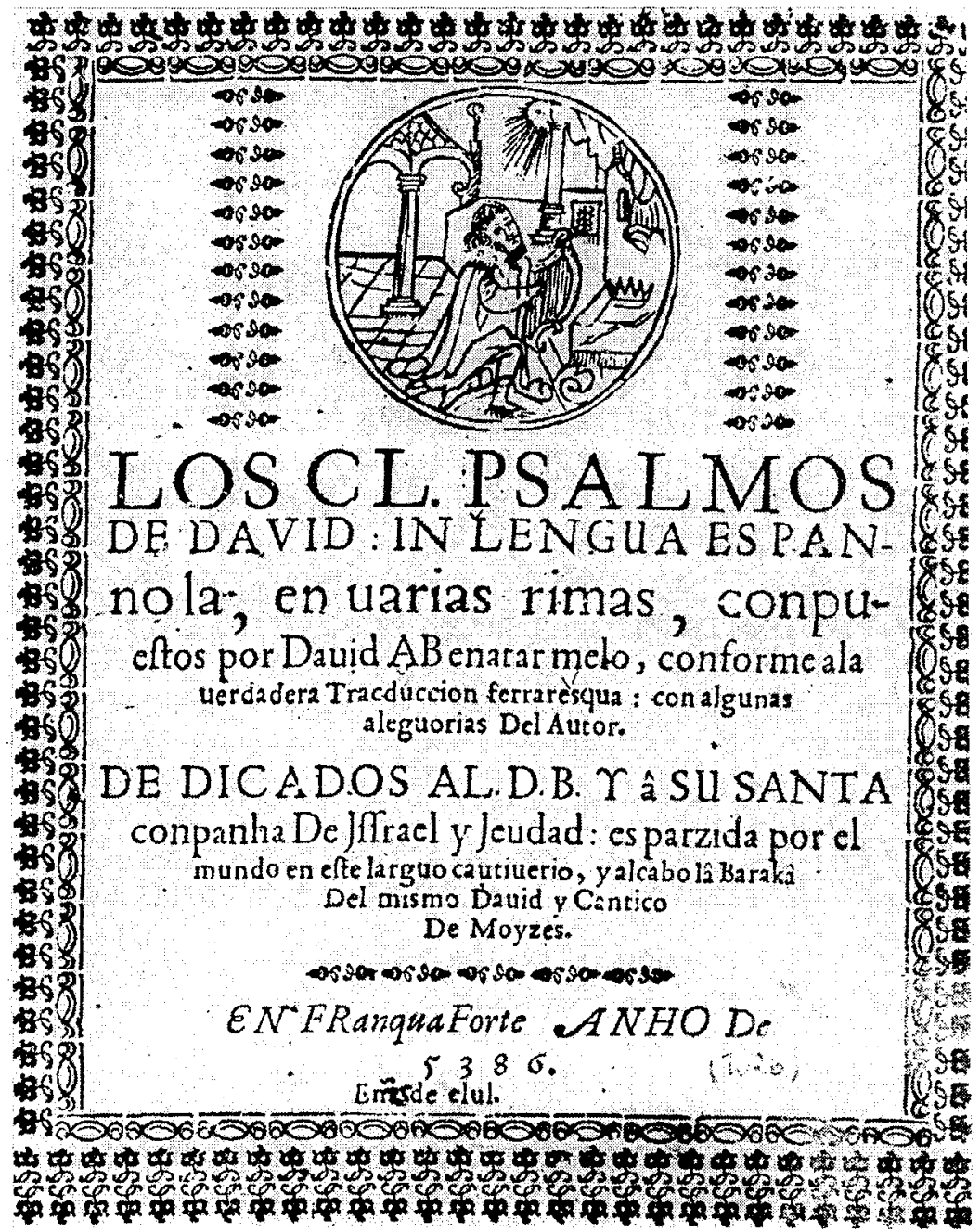

David Abenatar Melo, Frontispiece to Los CL Psalmos (Frankfurt 1626). 
The greatest printing enterprise in Frankfurt's environs were the Wechsel-Aubri editorial houses, ever active in protecting continental intellectualism, high creativity, and religious heterodoxy (Evans $1975: 38,43-45,48)$. As we shall see below, the Wechsel-Aubri presses were responsible for numerous publications of books dealing with the Iberian Peninsula: be it in creative literature, history (secular, military and ecclesiastical), the physical sciences, medicine, and geographical exploration. They were also actively engaged in divulging the Greco-Roman classics by rendering them to high German. Neither were Frankfurt-am-Main presses strangers to Old Testament-inspired works and editions, many requiring Hebrew typeface (Zafren 1997:231-271, and Wirth 1996 nos. 2-3).

When the Amsterdam Sephard Joseph de Cáceres wrote the preface to his Los siete días de la semana (Amsterdam $5372=$ 1616), he was explaining a truism likely applicable also to the rival printing emporium in Frankfurt: «Considere el lector que estamos fuera de España y que los impresores están muy remotos en la impresión castellana, y que yo también soy nobicio en semejantes cosas». The frontispiece for David Abenatar Melo's Spanish translation of the Book of Psalms (Frankfurt 1626), 'printed at the author's personal expense', registers at least thirty major and minor errors in standard typography, orthography, and syntax with respect to the Spanish language ${ }^{14}$, an indication that whoever assumed responsibility for the typesetting and subsequent printing was marginally familiar with Spanish and unable to completely correct authorial errors.

The counter argument also fails to acknowledge the following documented facts.

1) In 1641, the Frankfurt-am-Main university professor of medicine, Johannus Jonstonus, penned many words of praise in honor of his Spanish-Jewish homologue Abraham Zacuto (see above).

2) Fuks and Fuks-Mansfeld (1987 no. 611), relate the editorial history of a treatise on the metrical construction of the Psalms with Hebrew text by Marcus Meirboom (Amsterdam 1698):

\footnotetext{
14 Examples are: $C L$. instead of $C L, I n$ instead of En, Espannola, uarias, conpuestos, Dauid, ABenatar melo, uerdadera, Tracduccion, ferraresqua, aleguorias, Del instead of del, De Dicados two words, $\Upsilon$ the Pythagorean letter instead of the more standardized Spanish-Greek $Y, \hat{a}$, conpanha, De instead of de, Jssrael, es parzida two words, larguo, cautiuerio, alcabo one word, lâ, Barakâ, Dauid, EN FRanquaforte, $A N H O$, and Emẽs handwritten addition on the printed page.
} 
The publisher and bookseller Hendrik Wetstein (1649-1726) came as a young man from Switzerland to Amsterdam and married in 1678. He learned his trade from Daniel Elsevier and started his business in 1676. He had bookshops in Amsterdam and Frankfurt on the Main and was one of the most important booksellers and publishers of Amsterdam. He had no printinghouse of his own and had his publications printed by others. Though the place of printing appears on the titlepage, Steinschneider doubts of this is really an Amsterdam edition and we agree with him. Steinschneider gives no further reasons for his doubt, but it is a remarkable fact that the quires are marked with German gothic characters in this edition which is most unusual in Amsterdam Hebrew printing, as normally the quires are marked with Hebrew numerals. The German lettering of the quires could be an indication of a German place of printing.

3) The same bibliographers (1984:33) write of Johannes Le Maire (1603-1657):

Maire was one of the most important printers of his day. $\mathrm{He}$ also traded in books, his own as well as those of other printers, and had a permanent bookshop in Frankfurt, where he could stock his books after the annual bookfair. The many books he printed are of excellent quality and this also applies to his few Hebrew books. He does not mention in any of his Hebrew books the names of compositors or other assistants.

They add the following footnote:

The existence of the shop of Maire in Frankfurt came to light after the death of Maire's son Dirck, who was printer and bookseller in The Hague. To repay the substantial loan which Maire had given to his son, Dirck's widow rendered him all the books which were in a room of the Frankfurt shop. See E. F. Kossman, Boekhandel te 's-Gravenhage tot het eind van de 18 eeuw, The Hague, 1937, 250.

Frankfurt am Main obviously competed on a vigorous commercial level with Amsterdam when it came to book printing in any one of the major European languages, and it was not unrare to find the same select bookdealers in both Protestant publishing capitals. For Sephardim from Amsterdam or Hamburg to have their works printed in Frankfurt would not have been an oddity; to the contrary, it would have been rather a commonplace. 
The following lists of additional Frankfurt-am-Main seventeenth-century imprints should also bolster our argument. Their provenance is: $\mathrm{HAB}$ (Collection of Rare Printed Books) ${ }^{15}$, HSA ${ }^{16}$, BNM ${ }^{17}$, and Evans' Appendix (1975). They provide tangible, strong connections between seventeenth-century Frankfurt-based publishing houses and Iberian and classical culture:

Amadis aus Frankreich[:] Sehr schöne historien. Alles auß Franzözicher in unser allgemein Teutsche Sprach transferiert. 1569 \& 1633. Gedruckt zu Franckfurt am Mayn: Sigmund Feyerabends.- HAB (1569), BNM (1633).

Aretini, Petri. 1623. Pornodidascalus, seu colloquium muliebre Petri Aretini, de astune savio horrendisq[ue] dolis, quibus impudicae muliebres inventuti incautai insidiantur, Dialogus, ex hispanico in latinum versus a Casp. Bartho. ib. 8. Frankfurt: Aubry, Schleich: Wechel.HAB.

AREzZO, Claudio Mario. 1603. Hispaniae situs. Francofurti.- HSA.

BArbosA, Pedro. 1625. Pet. Barbosae ... Tractatus absolutissimi: I, De Matrimonio ... Francofurti: typis Hartmanni Palthenii; sumptibus Haeredum D. Zachariae Palthenii.- BNM.

BARCLAY, John. 1623; 1626-1627. Argenis. Frankfurt: Aubrey \& Schleich.- HAB.

BARTH, Kaspar. 1623. Fabularum Aesopiarum. 5. Phoenix. Psalmi 17. Frankfurt.- HAB.

- 1626. Phoenix. Frankfurt: Aubrey \& Schleich.- HAB.

BEN ISRAEL, Menasseh. 1632. Conciliator. Frankfurt.-BNM, HSA.

BEn Simeon, Uri. [n.d.]. Calendarium Palaestinorum. Tr. J. Christmann. [Frankfurt:] Vidua J. W. impens. P. Kopffii.- Evans.

La Biblia, que es, los sacros libros del vieio y nueuo testamento. 1622 [1569?]. [Frankfurt am Main?].- HSA.

BlanCAS, Jerónimo de. 1603. Regum aragoniae series, elogiaque imaginibus. Francofurti.- HSA.

BRY, Theodore de. 1590-1634. Collectiones peregrinationum in Indiam orientalem et Indiam occidentalem. Francofurti et Oppenheimii.HSA.

-. 1598-1623. Idem. Francofurti: Ioan Fridericus Weissius.- HSA.

Caramuel Lobkowitz, Juan. 1654. Metalogica Disputationis. Frankfurt.- BNM.

\footnotetext{
${ }^{15}$ Refer to its unpublished card catalog or Ortskatalog / Place of Publication Catalog, and MeßKatalog (= Frankfurt annual bookfair catalogs) collection.

${ }^{16}$ Refer to its Rare Books before 1800 Catalog.

${ }^{17}$ Refer to its On-Line Catalog of Rare Printed Books 1600-1700; BNM.es.
} 
CARDoso, Fernando Rodrigo. 1620. Tractatus Absolutissimus Ferdinando Roderici Cardosi In Arte Apollinea. Frankfurt.- HAB.

CARTAgenA, Alfonso de. 1603. Rerum hispanorum. Francofurti.- HSA.

CASAS, Bartolomé de las. 1665. Umbständige warhafftige beschreibung der Indianischen Ländern. [Frankfurt am Main?].- HSA.

Cervantes SaAvedra, Miguel de. 1648. Don Kichote de la Mantzscha, das ist: juncker Harnusch auß Fleckenland. Auß hispanischer Spraach in hoch teutsche ubers. Frankfurt: Götzen.- BNM.

- Don Kichote de la Mantscha. 1669. Frankfurt: Thomae Matthiae Götzen; 1682 Basel \& Frankfurt: Dü Foür in Genff; and 1683 Abentheurliche Geschichte, Basel und Frankfurt: Dü Foür in Genff.- BNM.

- 1624. "Rinconete y Cortadillo». Historia von Isaac Winckelfeldern und Jobst von der Schneid ... Bescrieben von Nicolaus Ulenhart. [Frankfurt?].- HAB.

---. 1753. Novelas ejemplares, deutsch. Satyrische und lehrreiche Erzehlungen des Michel de Cervantes Saavedra. Frankfurt \& Eßlingensche.- HAB.

Colombo, Cristoforo. 1603. Epistola de insulis nuper inventis. Francofurti.- HSA.

Conestaggio, Girolamo. 1603. De Portugaliae coniunctione cum regno castellae, historia. Francofurti.- HSA.

CosTA, Joannes Baptista. 1606. Novus de quota et rata siue de congrua in iure rerum partitione tractatus. Francofurti: E Collegio musarum Nouenarum Paltheniano.- HSA.

EBERT, Adam Praeses. 1687. Dissertatio academica de justitia actionum Philipi II, Hispaniae \& Indiarum regis, ad diem 28 maj., publicae eruditorum censurae exhibiturus Gustavus Andreas Bornemann. Francofurti eis Viadrum: Literis Friderici Eichornii.- HSA.

EULOGIUs [Saintly Archbishop of Toledo]. 1608. Ed. Ambrosio Morales. Divi Eulogii cordubensis opera. Francofurti.- HSA.

Franco, Niccolò. 1616. Diálogos satíricos. Trad. por Francisco de Cáceres. Francaforte: 1 de diciembre de 1616.- BNM A EH 12H78, A UB 563G27, R8237, R13382 (a).

- Idem. 1617. Amsterdam: Theodore Vocquil.- HSA.

García Matamoros, Alfonso. 1603. De academiis, et doctis viris hispaniae. Francofurti.- HSA.

GOES, Damião de. 1603. De bello cambaico secundo. Francofurti.- HSA.

- 1603. Diensis nobilissimae carmaniae seu Cambaiae urbis oppugnatio. Francofurti.- HSA.

-.1603. Epistola ad Io. Iacobum Fuggerum pro defensione hispaniae. Francofurti.- HSA.

- 1603. Fides, religio, moresque Aethiopum sub imperio Preciosi Ioannes. Francofurti.- HSA. 
-1603. Hispania Damiani a Goes. Francofurti.- HSA.

- 1603. Vita, collecta potissimum e scriptis eius. Francofurti.- HSA.

- 1603. Urbis olisiponis descriptio. Francofurti.- HSA.

GomezII, Dn. Antonii I. C. 1617. Hispani, Commentarius ad leges Taurinas. Francofurti: Ioannem Treutelium.- HAB.

Gómez DE CASTRO, Álvaro. 1603. De rebus gestis a Francisco Ximenio Cisnerio. Francofurti.- HSA.

Gómez Miedis, Bernardino [Bishop of Albarracín]. 1603. De vita \& rebus gestis Iacobi I. regis Aragonum. Francofurti.- HSA.

HERBORN, Nicolaus. 1617. Nothwendiger discurss und eygentliche beschreibung Americae. Franckfurt am Mayn: Nicolaum Hoffman.- HSA.

Herrera Tordesillas, Antonio de. 1623. Descripción de las Indias Occidentales. Deutsch. Frankfurt: de Bry.- HAB.

IDATUS [Bishop of Chaves]. 1608. Chronologia ex Idacio collectore quodam Caroli Magni aequali. Francofurti.- HSA.

ISIDORUS [Bishop of Sevilla]. 1603. Tractatus de claris praesertim hispaniae scriptoribus atque episcopus, cum appendicibus. Francofurti.HSA.

JiMÉnEZ DE RADA, Rodrigo [Archbishop of Toledo]. 1603. Rerum in Hispania gestarum libri IX. Francofurti.- HSA.

JOANNES [Bishop of Gerona]. 1608. Chronicon. Francofurti.- HSA.

Jỗo III [King of Portugal]. 1603. Epistola ad s.d.n. Paulum III, pont. max. Francofurti.- HSA.

_- 1603. Litterae ad Clementem pontificem VII. Francofurti.- HSA.

LebriJA, Antonio de [Elio Antonio Martínez de Cala y Jarana]. 1603. De bello navariensi, libri duo. Francofurti.- HSA.

- 1603. Rerum a Fernando et Elisabe. Francofurti.- HSA.

MAIMONIDES, Moseh ben. 1613. Livro intitulado thesuba que he, contrition, en el qual se tratan Todos modos della. Conpuesto por o admiravel Chacham Rvbi [sic] Moseh do Aegypto. E agora nouanene [sic] Tradicido con fedilidade de Hebraico en Hespañol. Por o Doctor Samuel da Sylva. E a sua custa impreso en Francafort. Anno 3573. A 10 de Siuan.- BNM R11084, R11085; however, R11084 bears a printed-in-Amsterdam frontispiece.

MANOEL I [King of Portugal]. 1603. Epistola de victoriis nuper in Africa habitis. Francofurti.- HSA.

Margarit y PAU, Juan de [Cardinal]. 1603. Paralipomenon hispaniae, libri $I[-X]$. Francofurti.- HSA.

MARIANA, Juan de. 1603. Historiae de rebus hispaniae. Francofurti.HSA.

—. 1606. Historiae de rebus hispaniae. Appendix. Francofurti: Claudium Marnium \& haeredes Ioan. Aubrii.- HSA.

MARINEUS, Lucius. 1603. De rebus hispaniae memorabilibus opus, libris 


\section{LIVRO. \\ INTITVL A \\ DO THESVBA QVE \\ HE, CONTRITION, EN EL qual Setratan Todos.modos della.}

\section{CONPVESTO POR O}

A DMIRAVEL CHACH AM RVBI Moreh do Figyto,

\section{Eagora Nossa nene Tradicidocon fedilidade de Hebraico en Fiefpiriol.}
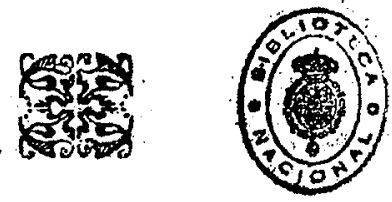

Por $\boldsymbol{\theta}$ Doctor Samwel da Sylva Ea fua cutta imprefo en Francafort. Anno, 357.3 Alo de Siuan.

XXII. Francofurti.- HSA.

Maimonides, Livro intitulado thesuba (BNM R11084). 
Modena, Jehuda Arje. 1693. De Ceremoniis, et Consuetudinis Hodie Judaeos inter receptis. Frankfurt.- HAB.

Morales, Ambrosio de. 1603. Corduba. Francofurti.- HSA.

MuXET DE Solís, Diego. [1624]. Comedias humanas, y divinas, y Rimas morales compuestas por ... Prostat ['Forthcoming']. Francofurti: Cornelium ob Egmont.- HAB Brussels ed.; listed as «Forthcoming» from a Frankfurt-am-Main press in the 1624 Meß Katalog (= printed Frankfurt bookfair catalog, HAB) = Catalogi Nundinales.

Nahumium, M. Jodocum. 1627. Prophetica Danielis. Franckfurt am Mayn: Johannis Ammonii.- HAB.

NuNES DE LEÃO, Duarte. 1603. Censurae in libellum de regum portugaliae origine, qui Fratris Iosephi Tfixerae nomine circumfertur; item de vera regum portugaliae genealogia liber. Francofurti.- HSA.

-_. 1608. Chronica dos reys de Portugal. Francofurti.- HSA.

NúÑEZ, Luis. 1608. Hispania sive populorum, urbium, insularum ac fluminum. Francofurti.- HSA.

Paulus, Hieronymous. 1603. De fluminibus et montibus hispaniae. Francofurti.- HSA.

PÉREZ, Andrés. 1626. Die Landstörtzerin Iustina Dietzin Picara. Franckfurt am Mayn: Johann Friderichen Wissen.- HAB.

PETRONII, T. 1629. Satyricon. Francofurti: Lucam Iennis.- HAB.

PITISCI, Bartholomaei, \& Abraham Sculteti. 1627. Meletemata Psalmica. Frankfurt.- HAB.

PONS DE ICART, Luis. 1603. Inscriptiones aliquot tarraconenses ex historia hispanica. Francofurti.- HSA.

Rerum hispanicarum scriptores aliquot ex bibliotheca Roberti Beli. 1579. Francofurti: Andreae Wecheli.- HSA.

Resende, Lucio André de. 1603. Antiquitatum lusitaniae \& de municipio eborensi lib. $V$. Francofurti.- HSA.

-_. 1603. Epistola historica, de aera hispanorum. Francofurti.- HSA.

- . 1603. Narratio rerum gestarum in India a Lusitanis, anno M.D. XXX. iuxta exemplum epistolae. Francofurti.- HSA.

RICCIO, Michele. 1603. De regibus hispaniae, libri tres. Francofurti.HSA.

ROCHEFORT, Charles de. 1668. Trans. Wilhelm Serlin. Historiche beschreibung der Antillen Inseln in America. Franckfurt: Wilhelm Serlins.- HSA.

RoJAS, Fernando de. 1624. Celestina: Pornoboscodidascalus Latinus. Trad. Lat. by Caspar Barthius. Frankfurt: Aubry \& Schleich.- HAB, HSA.

SÁNCHEZ dE ARÉvalo, Rodrigo [Bishop of Zamora]. 1603. Historiae hispanicae. Francofurti.- HSA.

SCHOTTIUS, Andreae. 1608. Hispaniae Bibliotheca seu De academiis ac 
bibliothecis: item elogia et nomenclator clarorum hispaniae Scriptorum qui latine disciplinas omnes illustrarunt. Frankfurt: apud Claudium Marnium \& haeredes Ioan Aubrii.- HAB, HSA.

TARAFA, Francisco. 1603. De origine ac rebus gestis regum Hispaniae liber. Francofurti.- HSA.

TASsO, Bernardo. 1626. La Gerusalemme Liberata. Deutsch. Frankfurt: Aubrey \& Schleich.- HAB.

TEIVE, Diogo de. 1603. Commentarius de rebus Lusitanis in India apud Dium gestis. Francofurti.- HSA.

TORRE, Alonso de la. 1623. Libro intitulado: Vision deleytable, y sumario de todas las sciencias. Traducido de Italiano en Español, por Francisco de Cáceres. Francaforte en 16 de Noviembre 1623 Años.- BNM R6854, R13168 (-a), R17337, U5056.

VAldesio, Jacobo. 1626. Praerogativa Hispaniae. Frankfurt: Guolfgangi Hofmanni.- HAB.

VALLA, Laurentis. 1603. De rebus a Ferdinando aragoniae rege gestis, libri tres. Francofurti.- HSA.

VALLÉS, Francisco de. 1582, 1590. Controversiarum medicarum et philosophicarum libri decem. Francofurti ad Moenum: Hearedes Andreae Wecheli.- HSA.

VASAEUS, Joannes \& Francisco TARAFA. 1603. Rerum hispanicarum chronicon. Francofurti.- HSA.

VERARDUS, Carolus. 1603. Expugnatio regni granatae. Francofurti.HSA.

ViPERANI, Giovanni Antonio [Bishop of Giovenazzo]. 1603. De obtenta portugalia a rege catholico Philippo historia. Francofurti.- HSA.

Wasero Thuringo, Casparo. 1625. Grammatica Hebraea, Etymologia \& Syntaxis absoluta. Francofurti: Aubrios \& Clementem Schleich.HAB.

ZIEGLER, Philippus. 1617. America. Franckfurt am Mayn: Nicolaum Hoffman.- HSA.

Zimarae, Marci Antonii. 1626. Philosophi Antri Magico-Medici. Pars Secunda. In qua Arcana naturae, sympathiae \& antipathiae rerum in Plantis, animalibus, animaliumque morbis \& partibus, signature internae rerum, sine vera \& viua anatomia maioris \& minoris mundi, Imaginum \& Figurarum Magicarum constructio, erectio \& effectus admirandi, omniumque corporis humani morborum, inprimis Podagrae, Hydropia, Pestis epidemiae, \& Cancri exulceratio cura Hermetica, Specifica, Characteristica, \& Magnetica, (adspersa etiam Galenica) continentur. Accesserunt Portae Intelligentiarum Sine Canones Hebraerorum, Chaldaeorum, Arabum, Aegyptiorum, Orphicorum, Pythagoraeorum, Graecorum \& Latinorum priscorum, quibus omnis veterum sophorum Sapientia, hactenus occultata, in apertam lucem producta, 
filiis verae doctrinae proponitur. Et Canones Hermetici De Spiritu. Francofurti: Typis \& Sumptibus Wechelianorum, apud Danielem \& Davidem Aubrios, \& Clementem Schleichium.

ZURITA Y CASTRO, Jerónimo. 1606. Indices rerum ab Aragoniae regibus gestarum ab initiis regni ad annum MCDX [and other works]. Francofurti.- HSA.

Ben Israel's, Ben Simeon's, Cáceres', Modena's, Maimonedes' and the converso Cardoso's Frankfurt-based publications, in addition to Abenatar Melo's ${ }^{18}$ and Mussaphia's (n. 2 above), give specific credibility to the city's attraction as a major publishing emporium eager to print works of Sephardic culture.

Several complementary entries may also support our argument: Rodrigo de Castro's 1614 Medicus-Politicus was published at Cologne (NUC) and also Hamburg that same year (Ex bibliopolio Frobeniano) (NUC); a Calendario Perpetuo de todos os Rase-Hodasim ... was printed at Frankfurt in 5385 (=1625/1626; YUSML); Abraham Zacuto's 1629 edition of De medicorum principium historia: Libri sex, was printed in Cologne (Coloniae Agrippinae) by the Johannis Frederici Stam Press (NUC); R. de Castro's 1668 Tractatus de natura muliebri seu disputationes ac lectiones Pisanae. Nunc primum in lucem editu was published at Frankfurt by Hermannum a Sande $(N U C)$; and a second edition of Menasseh BenIsrael's De Resurrectione Mortuorum: Libri Tres, saw first light at Emilio Spinnikir's Dutch Gronigen press in 1676 (HSA). Suffice it to say, it would be difficult to argue that Catholic Cologne Lutheran, Frankfurt (with its strong Calvinist-inspired printing business), and Hamburg, and Calvinist Dutch Gronigen were veiled places of publication for Calvinist Amsterdam. In addition, Casparus Barthius' Latin translation of Gaspar Gil Polo's La Diana enamorada (1625), under the title Erotodidascalus. Sive, Nemoralium: Libri V, cum figuris aeneis, was printed at Hannover by the reputable Calvinist printers: «Typis Wechelianis, apud Danielem \& Davidem Aubrios \& Clementem Schleichium» (HSA).

${ }^{18}$ Other Spanish-language contemporary translations of the Psalms are Antonio de CÁCEREs, Paraphrasis de los Psalmos de David (Lisboa 1616; HAB TC $4^{\circ} 40$ ), and the anon. and Christianized Los Psalmos de David y otros (Amsterdam: Iacob Wachter, 1625; BNM U8529). 


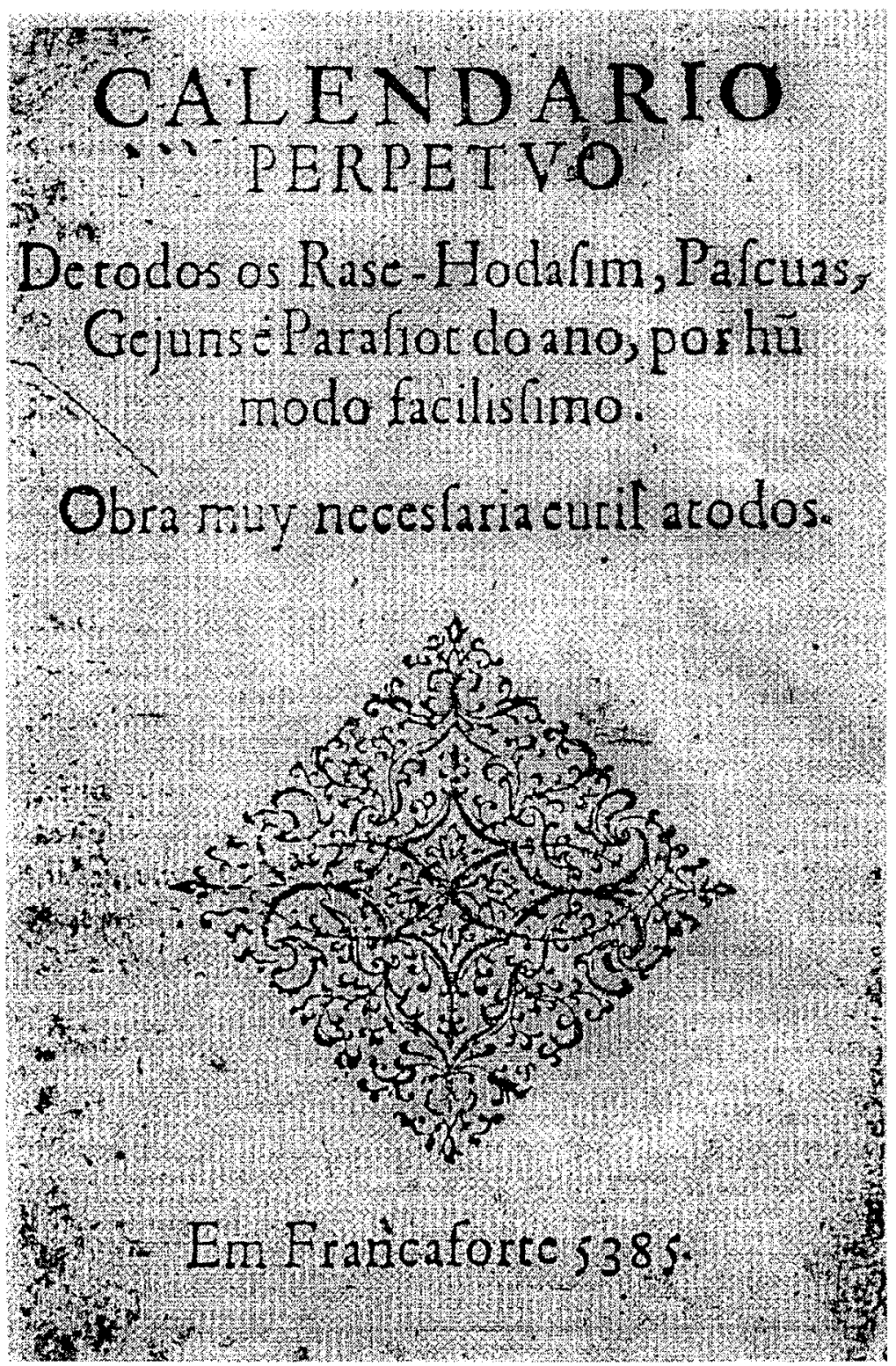

Anon., Perpetual Calendar of Jewish Holidays (Frankfurt 1625/1626), originally in the YUSML Collection; currently lost. 


\section{BIBLIOGRAPHY}

Abenatar Melo, David. 1626. Los CL. Psalmos / de David: in [sic] Lengua Espan/nola, en uarias rimas, conpu/estos por Dauid Abenatar melo, conforme a la / uerdadera Tracduccion ferraresqua: con algunas / aleguorias Del Author. / DE DICADOS [sic] AL. D.B. YâSUSAN$T A$ / conpanha De Jssrael y Jeudad: es parzida [sic] por el / mundo en este larguo cautiuerio, a alcabo [sic] lâ Barakâ / Del mismo Dauid y Cantico / De Moyzes. / EN Franquaforte ANHO De / 5386. / E més de elul.- UBH Scrin. A/441, BNM R11434.

ADLER, J. 1982. «Technopaignia, carmina figurata and BilderReime: seventeenth-century figured poetry in historical perspectives», in Comparative Criticism Yearbook 4 pp. 107-147.

ADLER, J., and U. ERNST. 1987. Text als Figur. Visuelle poesie von der Antike bis zur Moderne. Wolfenbüttel: Herzog August Bibliothek.

Ben IsRael, Menasseh. 1635. De Creatione Problemata xxx. Amsterdam: Typis \& sumptibus Auctoris.- HAB 1034.29 Th. (3).

-1632. Conciliator, sive De Convenientia locorum S. Scripturae, quae pugnare inter se videntur. Opus ex vetustis, \& recentioribus omnibus Rabbinis, magna industria, ac fide congestum. / Esto es Conciliador, o De la conveniencia de los Lugares de la Santa Escriptura, que repugnantes entre sí parecen. Obra ansí de los antiguos, como modernos sabios, con grande industria, y fe coligida. Francofurti: Auctoris impensis.

-. 1639. De termino vitae, Libri tres. Quibus veterum Rabbinorum, ac recentium doctorum, da hac controversia sententia explicatur. Amstelodami: Typis \& sumptibus authoris.- HAB 1248.1 Th. (2).

BoCARro FrancÊs, Imanuel [alias Jacob Rosales]. 1644. Armatura medica sive modus addiscendi medicinam. Lyon.

BOER, Harm den. 1988. «Ediciones falsificadas de Holanda en el siglo XVII: escritores sefarditas y censura judaica», in Varia bibliographica: Homenaje a José Simón Díaz, Ed. Kurt Reichenberger. Kassel: Reichenberger, pp. 99-104.

- 1989. «Francisco de Cáceres, Litterator en Koopman in Talen te Amsterdam», in Een Gulden Kleinood: Liber Amicorum angeboden aan de heer D. Goudsmit. Apeldoorn: Garant, pp. 55-70.

-. 1992. «La literatura hispano-portuguesa de los sefardíes de Amsterdam en su contexto histórico-social (siglos XVII y XVIII)», Ph.D Dissertation, Universiteit van Amsterdam.

-_- 1995. La literatura sefardí de Amsterdam. Alcalá de Henares: Universidad de Alcalá / Instituto Internacional de Estudios Sefardíes y Andalusíes. 
Brockhaus Enzyklopädie. 1967. 20 vols. Wiesbaden: F. A. Brockhaus.

Brown, Kenneth. 1999a. «La Poetisa es la luna que con las de Apolo viene: nuevos datos sobre y textos de varias poetisas sefardíes de los siglos XVII y XVIII", in La creatividad femenina y las trampas del poder. 2 vols. Kassel: Reichenberger, vol. II pp. 439-480.

_- 1999b. «Spanish, Portuguese, and Neo-Latin Poetry Written and/or Published by Seventeenth- and Eighteenth-Century Sephardim from Hamburg and Frankfurt», Sefarad 59 pp. 3-42.

Calendario Perpetuo De todos os Rase-Hodasim, Pascuas, Gejuns é Parasiot do ano. Francaforte, 5385 [= 1625/1626].- Sterling Memorial Library, Yale University, Judaica Bg19p/625c. [Lost.]

Cardoso, Fernando Rodrigo. 1620. Tractatus Absolutissimus Ferdinandi Roderici Cardosi In Arte Apollinea quondam conimbricae Professoris primarii: postea vero Regiae Maiestatis Regnorum Lusitaniae protomedici dignissimi. Francofurti ad Moenum: Typis Pauli Iacobi; Impensis Iacobi de Zetter.- HAB 58.8 Phys. MF (3).

CASTRo, Francisco de. 1641. Metamorfosis a lo moderno en varios epigrammas, cada uno con su argumento, y declaración, con una «Canción del Chaos, y de las quatro edades del Mundo. Obra de graçioso entretenimiento». Florencia: Amador Massi y Lorenzo Landi.- HSA.

CAstro, Estêvão Rodrigues de. 1967. Obras poéticas em português, castelhano, latim, italiano, Ed. Giacinto MANUPELLA. Coimbra: Universidade.

Castro Lusitani, Roderici a [sic]. 1614. Medicus-Politicus. Hamburgi: Frobeniano.- HAB 34 Medica.

_- [1603] (Hamb.), 1604 (Hamb.), 1614 (Coloniae). De universa mulierum morborum medicina, novo et antehac a nemine tentato ordine opus absolutissimum ... 2 vols. Hamburgi: Frobeniano.- HAB $17 \mathrm{Me}$ dica.

. 1617 De universa muliebrium morborum medicina ... Pars prima theorica $[=$ Pars secunda] ... In quibus cuncta, quae ad mulieris naturam, anatomen, semen, menstruum, conceptum, uteri gestationem, foetus formationem, \& hominis ortum attinet ... explicantur. 2 ed. auctior et emendatior. Hamburgi: Ex bibliopolio Frobeniano-- NUC.

Catalogue of Books Printed in the German-Speaking Countries and of German Books Printed in other Countries from 1601 to 1700 now in the British Library. 1994. 2 vols. London: The British Library.

Catalogus Novus Nundinarum. 1595-1621.- HAB Q37.41 Helmst (1-19).

Catalogi Nundinales 1571-1852. Die Frankfurter und Leipziger MeßKatalog der Herzog August Bibliothek Wolfenbüttel. Zusammengestellt von 
Wolfgang Borm. Band 5. Repertorien zur Erforschung der Frühen Neuzeit Herzog August Bibliothek, Wolffenbüttel [1982].- HAB.

Catalogi Nundinales. [Frankfurt-am-Main bookfair catalogs, corresponding to the years] $1610-1612,1614,1616-1618,1620-1625,1628-1631$, 1634-1635, 1637-1638, 1641, 1645-1650. Francofurti.- HAB.

Catalogus Universalis Pro Nundinis Francofurtensibus Autumnalibus, De Anno MDCLXXXVI (1686). Hoc est, Designatio omnium Librorum, qui hisce Nundinus autumnalibus vel novi, vel emendatiores \& auctiores prodierunt. Francofurti: Haeredum Sigismundi Latonis.- HAB.

Codex Nundinarius Germaniae Literatae Bisecularis. Meß-Jahrbücher des Deutschen Buchhandels von dem Erscheinen des ersten Meß-Kataloges im Jahre 1564 bis zu der Gründung des ersten Buchhandler-Bereins im Jahre 1764. 1850. Halle: Schwetschke.- HAB.

CORNU, G. 1983. «Écriture, peinture: des calligrammes aux pictogrammes», Semiótica 44 pp. 123-135.

Cózar, R. de. 1991. Poesía e imagen: Formas difíciles de Ingenio Literario. Sevilla: El Carro de la Nieve.

D'Ors, M. 1977. El caligramma, de Simmias a Apollinaire. Pamplona: Eunsa.

David-Peyre, Yvonne. 1973. «Le Medicus Politicus de Rodrigo de Castro et la Musicothérapie», Revue d'Histoire de la Médecine Hébraique 103 pp. $69-74 ; 105$ pp. 133-137.

Deonna, W. 1926. «Les poèmes figurés», Revue de Philologie 50 pp. 187193.

Díez BoRque, José María. 1992. Literatura de la celebración: Verso e Imagen en el Barroco español. Madrid: Comunidad de Madrid.

- - 1993. Verso e Imagen: Del Barroco al Siglo de las Luces. Madrid: Calcografía Nacional.

Encyclopaedia Judaica. 1971. Jerusalem: Keter.

Evans, R. J. W. 1975. The Wechel Presses: Humanism and Calvinism in Central Europe 1572-1627, Past \& Present / Supplement 2. The Past and Present Society. The Seacourt Press, Ltd. Oxford.

FARINELli, Arturo. 1892. Die Beziehungen zwischen Spanien und Deutschland in der Litteratur der beiden Länder. I. Teil: bis zum 18. Jahrhundert. Berlin: A. Haack.

FAUST, Jürgen, and Michael STUdemund-HALÉVy. 1997. Sefardische Gräber in Schleswig-Holstein. Glückstadt: Verlag J. J. Augustin.

FLOR, Fernando R. de la. 1997. «Metamétrica: La experiencia de los límites en la poesía de la edad moderna», Ínsula 603-604 (mar.-abr.) pp. 5-7. 
Friedenwald, Harry. 1944 [1967]. Jews and Medicine. 2 vols. Baltimore [New York]: The Johns Hopkins U. P. [Ktav].

-_. 1946. Jewish Luminaries in Medical History and a Catalogue of Works Bearing on the Subject of the Jews and Medicine from Private Libraries. Baltimore: The Johns Hopkins U. P.

FUKS, L., and R. G. FUKS-MANSFELD. 1984 (part 1) and 1987 (part 2). Hebrew Typography in the Northern Netherlands 1585-1815. 2 parts. Leiden: Brill.

GANDELMAN, C. 1986. Le regard dans le text: Image et écriture du Quattrocento au XX siècle. Paris: Klincksieck.

GRILLI, Guiseppe. 1985. «Poesia artificiosa e metametrica nella letteratura catalana», in Annali Dell'Istituto Universitario Orientale. Napoli, Sezione Romana 27/2 (July) pp. 293-356.

GrIMAL, Pierre. 1984 [1965]. Diccionario de mitología griega y romana. Barcelona: Paidos.

GrözINGER, Karl E. (Ed.). 1997. Jüdische Kultur in Frankfurt am Main von den Anfängen bis zur Gegenwart. Wiesbaden: Harrassowitz.

HAtherLy, A. 1995. A casa das musas. Lisboa: Editorial Estampa.

Herzog August Bibliothek, Wolfenbüttel, Germany. Ortskatalog [Unpublished cart catalog of rare books' place of publication]. See also Kata$\log$.

Hocke, G. R. 1959. Manierismus in der litteratur. Hamburg: Rowoholt.

HOFFMEISTER, Gerhart. 1976. Spanien und Deutschland: Geschichte und dokumentation der literarischen Beziehungen. Berlin: Erich Schmidt. [España y Alemania. Madrid: Gredos, 1980.]

Katalog der Herzog-August Bibliothek Wolfenbüttel [Published Manuscript Catalog]. 1963. Frankfurt am Main: Klostermann. 15 tomes. See also Herzog August Bibliothek.

KAySERLING, Meyer. 1858, 1859, 1860, 1861. «Zur Geschichte des jüdischen Ärzte: Die familie de Castro», Monatsschrift für Geschichte und Wissenschaft des Judentum 7 pp. 393-396; 8 pp. 161-170; 9 pp. 92-98; 10 pp. 38-40.

KELlEnbenZ, Hermann. 1956. «Dr. Jakob Rosales», Zeitschrift für Religions- und Geistesgeschichte 8 pp. 345-354.

KÖRNER, Karl-Hermann. 1992. «Heute bin ich in Hamburg, morgen in Altona': zu Abraham Meldola und seiner Nova Grammatica Portugueza von 1785», in Aufsätze zur Portugiesischen Kulturgeschichte, Eds. D. Briesemeister, H. Flasche, K.-H. Körner, no. 20 Band 1988-1992, pp. 201-214. Münster: Aschendorff.

- 1994. «Sobre Abraham Meldola e a sua Nova Grammatica Portugueza de 1785», in STUDEMUND-HALÉVY 1994b pp. 375-381. 
LARAS, Giuseppe. 1978. «I marrani di Livorno e l'Inquisizione», in Atti del Convegno "Livorno e il Mediterraneo nell'Età Medicea», pp. 82104. Leghorn: Bastogi.

Lemos, Maximiano. 1909. Zacuto Lusitano. A sua vida e a sua obra. Porto: Eduardo Tavares Martins.

- Maximiano Augusto de Oliveira. 1895. «Médicos portuguezes no extrangeiro. Estevam Rodrigues de Castro», in Archivos de História da medicina portuguesa: Primeira Série vol. 5 pp. 44-48, 76-80, 106-111. Porto.

LiEdE, A. 1963. Dichtung als Spiel. Studien zur Unsinnpoesie an der Grenzen der Sprache. Berlin.

LÜBBECKE, Fried. 1948. Fünfhundert Jahre Buch und Druck in Frankfurt am Main. Frankfurt am Main: H. Cobet Verlag.

MS. HAB 13 Gud. Lat. 21 [Extravagantes = Miscellany; no title].

MS. HAB 17 Blankenburg (früher 9) fol. 384r-v. [Published mss. catalog description, title: Fürstenbriefe des XVI. und XVIII Jahrhunderts.]

MÉchoulan, Henry. 1990. «Francisco de Cáceres traducteur juif espagnol de La Sepmaine de Guillaume de Saluste du Bartas», in Estudos portugueses: Homenagem a António José Saraiva pp. 133-149. Lisboa: Ministério de Educação, Instituto de Cultura e Língua.

Meldola, Abraham. 1785. Nova Grammática Portugueza dividida em VI Partes a saber: 1 Orthographia, 2 Etymologia, 3. Syntaxe, 4 Prosódia cum Supplemento, 5. Lavores da Língoa, 6. Miscellánia. Hamburgo: M. C. Bock, a custas do Author.- HAB KK 30.

The National Union Catalog Pre-1956 Imprints. 1968. 565 tomes and Supplement 69 tomes. London and Chicago: Mansell.

PAQUET, Alfons. 1924. Frankfurt als Bücherstadt und das Rhein-Maingebiet als heimat des Buchdrucks und Buchgewerbes. Frankfurt am Main: R. Th. Hauser \& Co.

Penney, Clara Louisa. 1965. Printed Books 1468-1700 in the Hispanic Society of America. New York: The Hispanic Society of America.

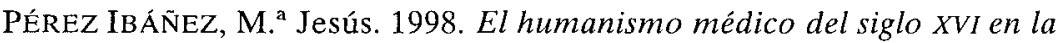
Universidad de Salamanca. Valladolid: Universidad.

PRAZ, Mario. 1964. Studies in Seventeenth-Century Imagery. London: Edizioni di Storia e Letteratura.

Rosales, Jacob: See also Imanuel Bocarro FrancÊS.

- . 1644. Regnum Astrorum Reformatum, Cujus Fundamentum, Caelestis Astronomiae Praxis. Tomus Primus. Hamburgi: Henrici Weineri.HAB 4.1 Astron. $2^{\circ}$.

Saraiva, António José. 1986. «Bocarro-Rosales and the Messianism of the Sixteenth Century», in Menasseh ben Israel and his World, Ed. Y. KAPLAN, pp. 240-243. Leiden: Brill. 
SCHLEINER, Winfried. 1994. «The Contribution of Exiled Portuguese Jews in Renaissance Medical Ethics», in The Expulsion of the Jews, Eds. R. B. WAdDington and A. H. Williamson, pp. 147-159. New York and London: Garland.

Studemund-HALÉVY, Michael. 1994a. Bibliographie zur Geschichte der Juden in Hamburg. München, New Providence, London, Paris: K. G. Saur.

_- (Ed.). 1994b. Die Sefarden in Hamburg: zur Geschichte einer Minderheit. Teil 1. Hamburg: Buske.

- 1995. «Epigrafia tumular luso-judaica em Hamburgo», in Actas do $4^{\circ}$ Congresso da Associação Internacional de Lusitanistas, Ed. M. F. ViEgAS BAUER-FIGUEREIDO, pp. 1081-1092. Lisboa: Lidel.

—. 1996. «Panorama de L'Épigraphe Funéraire Judéo-Portugaise à Hambourg», in Mémoires Juives d'Espagne et du Portugal, Ed. E. Benbassa, pp. 105-125. Paris: Publisud.

_. 1997a. «Hamburger Autoren und ihre Bücher», Lusorama 33 (June) pp. $41-72$.

- - 1997b. «Die portugiesisch-spanischen Grabinschriften in Norddeutschland: Glückstadt und Emden", Aschkenaz - Zeitschrift für Geschichte und Kultur der Juden 7/2 pp. 389-439.

_. 1997c. Die Sefarden in Hamburg: Zur Geschichte einer Minderheit. Vol. II. Hamburg: Buske.

—_. 1997d. «Sephardischer Buchdruck in Hamburg: erster Teil», Lusorama 32 (March) pp. 85-101.

—. 1997e. «Sephardischer Buchdruck in Hamburg: zweiter Teil», Lusorama 33 (June) pp. 41-72.

_-_. 1997f. «Les Sépharades Oubliés D’Allemagne», La Lettre Sépharade 23 (Sept.) pp. 10-11.

-_. 1997g. «Sephardische Bücher und Bibliotheken in Hamburg», Menora 8 pp. $150-180$.

- 1999a. A Jerusalém Do Norte: Sefardische Juden in Hamburg. [Printed Exhibition Catalog] Hamburg.

—. 1999b. «Zwischen Amsterdam und Hamburg: Sephardische Bücherschicksale im 17. Jahrhundert», in Spanien und die Sepharden: Geschichte, Kultur, Literatur, Eds. N. REHRMANN and A. KOECHER'T, pp. 69-92. Sonderdruck aus Romania Judaica 3.

---. 1999c. «Roteiro de uma vida: Fernão Alvares Melo alias David Abenatar Melo", Ibn Marvan (forthcoming).

TiEmann, Hermann. 1970 [1939]. Lope de Vega in Deutschland. Georg Olms: Hildesheim, New York [Hamburg: Reprografischer Nachdruck 
der Ausgabe Hamburg. Mitteilungen aus der Bibliothek der Hansestadt Hamburg, N. F. Bd. 5].

—_. 1971 [1936]. Das Spanische Schrifftum in Deutschland von der Renaissance bis zur Romantik. Georg Olms: Hildesheim, New York [Hamburg: Reprografischer Nachdruck der Ausgabe Hamburg. IberoAmerikanische Studien, Bd. 6].

WEINSTEIN, Rochelle. 1997. «The Storied Stones of Altona: Biblical Imagery on Sephardic Tombstones at the Jewish Cemetery of AltonaKönigstraße, Hamburg», in STUdEMUND-HALÉVY 1997c pp. 551-660.

WinIGER, V. S. [1931?]. Grosse Judische National-Biographie. Leipzig: Gustav Brauns.

WIRTH, Bernhard (Compiler). 1996. «Gedruckt zu Franckfurt am Mayn» 100 Bücher aus der Frankfurter Drunk- und Verlagsgeschichte 15111930. Frankfurt am Main: Stadt- und Universitätsbibliothek.

Yerushalmi, Yosef Hayim. 1971. From Spanish Court to Italian Ghetto, Isaac Cardoso: A Study in Seventeenth-Century Marranism and Jewish Apologetics. New York and London: Columbia University Press.

ZaCuTuS Lusitanus, Abraham. 1637. Historiarum Medicarum: Liber Tertius. Amstelodami: Laurentii. [General title: De medicorum principium historia ... In quo medicinales omnes medicorum principum historiae, de vitalium, et naturalium partium affectibus compendioso ordine proponunten. Amstelodami: Laurentii, 1632-1642. 11 vols.].- HAB 59.7 Medica.

_-. 1637. Historiarum ...: Libro [sic] Quartus. Amstelodami, Laurentii.HAB 59.8 Medica.

-_. 1637. Historiarum ...: Liber Quintus. Amstelodami, Laurentii.HAB 59.8 Medica [bound with the fourth vol.].

- 1641. Historiarum ...: Liber Septimus. Amstelodami, Laurentii.HAB 59.9 Medica.

_.. 1642. Historiarum ... Liber Ultimus [= 11]. Amstelodami, Laurentii.HAB 59.10 Medica.

- - [n.d.]. Tratado sobre medecina que fez o Doutor Zacuto para seu filho lexar consigo quando se foy para o Brazil. Unedited MS. U. S. National Library of Medicine (Bethesda, Maryland).

ZAFREN, Herbert C. 1997. «Hebrew Printing by and for Frankfurt Jews to 1800», in GRÖZINGER 1997 pp. 231-271.

ZÜLCH, Walter Karl, and Gustav MORI. 1920. Frankfurter Urkundenbuch zur FrühGeschichte des Buchdrucks. Frankfurt am Main: Joseph Baer \& Co.

[Continuará] 